\title{
Biomass production of the last remaining fen with Saxifraga hirculus in Switzerland is controlled by nitrogen availability
}

Journal Article

Author(s):

Olde Venterink, Harry; Vittoz, Pascal

Publication date:

2009

Permanent link:

https://doi.org/10.3929/ethz-b-000013210

Rights / license:

In Copyright - Non-Commercial Use Permitted

Originally published in:

Botanica Helvetica 118(2), https://doi.org/10.1007/s00035-008-0861-z 


\title{
Biomass production of the last remaining fen with Saxifraga hirculus in Switzerland is controlled by nitrogen availability
}

\author{
Harry Olde Venterink ${ }^{1}$ and Pascal Vittoz ${ }^{2}$ \\ ${ }^{1}$ Institute of Integrative Biology, Plant Ecology, ETH Zurich, Universitätstrasse 16, CH-8092 \\ Zurich, Switzerland; e-mail: harry.oldeventerink@env.ethz.ch \\ 2 Department of Ecology and Evolution, University of Lausanne, Building Biophore, CH-1015 \\ Lausanne, Switzerland
}

\begin{abstract}
Olde Venterink H. and Vittoz P. 2008. Biomass production of the last remaining fen with Saxifraga hirculus in Switzerland is controlled by nitrogen availability. Bot. Helv. 118: 165 - 174.

For conservation management of endangered plants it is important to know which nutrient(s) control growth of the vegetation, because maintenance of low nitrogen $(\mathrm{N})$, phosphorus $(\mathrm{P})$ or potassium $(\mathrm{K})$ availability requires different management measures. The aim of this study was to determine the type of nutrient limitation for the vegetation in the last remaining site with Saxifraga hirculus in Switzerland, using nutrient ratios in the aboveground vegetation as an indicator. We made vegetation relevees, collected biomass of the vascular plants, and took soil samples in three plots at this site. The biomass was very low $\left(152-231 \mathrm{~g} \mathrm{~m}^{-2}\right)$, and all three plots were clearly $\mathrm{N}$-limited with $\mathrm{N}: \mathrm{P}$ ratios of $7-8$. Soil extractable $\mathrm{N}$ concentrations were generally low, and $\mathrm{P}$ and $\mathrm{K}$ concentrations were moderate to high, which was consistent with the indicated $\mathrm{N}$ limitation. Hence conservation management first of all needs to prevent $\mathrm{N}$-enrichment, and needs to avoid increased mineralization rates through drainage, or the accumulation of $\mathrm{N}$ in the system from atmospheric deposition. Therefore $\mathrm{N}$ output seems required through for instance grazing or mowing. The current grazing management seems to function well, since total aboveground biomass is very low and $S$. hirculus has a high abundance in this last remnant.
\end{abstract}

Key words: Endangered plant, fen, nutrient limitation, N:P stoichiometry, red list species, wetland. 


\section{Introduction}

Saxifraga hirculus L. is one of the rarest and most endangered plant species of western and central Europe. It got extinct in many European countries such as Austria, Germany and The Netherlands (Weeda et al. 1985, Vittoz et al. 2006). It occurs at only one site in Switzerland, a few sites in France, Ireland, England and Scotland, and has its main occurrence in Scandinavia, Poland, the Baltic countries and Russia (Vittoz et al. 2006). The Swiss site is of international importance for conservation because of its isolated position in Central Europe and its relatively large population (Welch 2002; Broennimann et al. 2005; Eggenberg and Landolt 2006; Vittoz et al. 2006). Partly because it is so rare, we know little about the habitat requirements of this species, but sites where it is still found have a stable water table close to the soil surface and a neutral to slightly acid pH (Vittoz et al. 2006).

Endangered plant species in European and Canadian wetlands have only been observed in sites with a low aboveground biomass of vascular plants $\left(<600 \mathrm{~g} \mathrm{~m}^{-2}\right.$; Moore et al. 1989; Wheeler and Shaw 1991; Wassen et al. 2005). Hence, besides direct habitat destruction, the loss of endangered species is likely to be related to nutrient enrichment and productivity increase (Bollens et al. 2001; Olde Venterink et al. 2001). Particularly $\mathrm{N}$ enrichment is widely thought to be a major cause for the loss of plant species from temperate terrestrial ecosystems. This view is based on a widespread increase in atmospheric $\mathrm{N}$ deposition (Galloway et al. 2004), and the results from field surveys and experiments showing that species richness correlates negatively to $\mathrm{N}$ enrichment (Bobbink et al. 1998; Stevens et al. 2004).

Olde Venterink et al. (2003) and Wassen et al. (2005) analysed the occurrence of endangered species at a large number of sites in herbaceous grasslands and wetlands along a N-deposition gradient in Eurasia (The Netherlands, Belgium, Poland, Siberia). They observed that many endangered species persisted better at sites where $\mathrm{P}$ was growth-limiting than at sites where $\mathrm{N}$ was limiting, and concluded that $\mathrm{P}$ enrichment has been at least as important as $\mathrm{N}$ enrichment for species loss in these ecosystems. $S$. hirculus occurred at five of the 274 sites of Wassen et al. (2005): one N-limited site in the Biebrza valley in Poland, one N-limited site in a wetland in Siberia, and three sites in a N\&P co-limited or P-limited wetland in the same area in Siberia.

Since the maintenance of $\mathrm{N}$-limited or P-limited ecosystems requires different management approaches (Verhoeven et al.1996; Olde Venterink et al. 2002b; Davidson and Howarth 2007) it is essential to understand relationships between endangered plants and the type of nutrient limitation. The aim of this study was to determine the type of nutrient limitation for the vegetation in the last remaining site of $S$. hirculus in Switzerland, using nutrient ratios in the aboveground vegetation as an indication.

\section{Materials and Methods}

The wetland Sèche de Gimel is located in the Jura Mountains, next to the col du Marchairuz (1310 m a.s.l.). It lays in a small valley, surrounded by wooded pastures, and offers a large diversity of ecological conditions (from basic fens to raised bog; Christe et al. 1990). S. hirculus populations are in the wettest parts, classified as Caricion lasiocarpae (Delarze and Gonseth 2008). The wetland is occasionally lightly grazed by young bovines, but the spots with $S$. hirculus had not been grazed yet during the growing 
season in which we took samples. A more complete description of the site is given in Vittoz et al. (2006).

For this study, the composition of the vascular plant community was recorded on 18 August 2006 in three $2 \times 2 \mathrm{~m}$ plots in dense $S$. hirculus populations. The plots were distributed along a $222 \mathrm{~m}$-long line, with 87 and $147 \mathrm{~m}$ between the plots. The plant nomenclature of the Swiss site follows Lauber and Wagner (2000) and the cover was estimated with the Braun-Blanquet (1964) scale. The same day, the vegetation was cut down to $1-2 \mathrm{~cm}$ above soil surface using $50 \times 50 \mathrm{~cm}$ frames (three subplots per $2 \times 2 \mathrm{~m}$ plot). Dry weight of the biomass of each subplot sample was determined after drying for 72 hours at $70^{\circ}$. Biomass samples were ground and analysed for $\mathrm{N}$ and $\mathrm{P}$ concentrations after Kjeldahl digestion. Total $\mathrm{N}$ and $\mathrm{P}$ concentrations in the digests were measured by means of a continuous flow injection analyser (FIAStar, Foss Tecator, Höganäs, Sweden). A second subsample was extracted with $0.5 \mathrm{M} \mathrm{HCl}$ and analysed on K concentrations, using atomic absorption spectrometry (Hunt 1982) (SPECTRAA 240 FS, Varian AG, Zug, Switzerland). We used the critical values of Olde Venterink et al. (2003) to determine the type of nutrient limitation, i.e.: N-limitation if $\mathrm{N}: \mathrm{P}<14.5$ and $\mathrm{N}: \mathrm{K}<2.1$; $\mathrm{P}-$ or $\mathrm{N} \& \mathrm{P}$ co-limitation if $\mathrm{N}: \mathrm{P}>14.5$ and $\mathrm{K}: \mathrm{P}>3.4$; K- or N\&K colimitation if $\mathrm{N}: \mathrm{K}>2.1$ and $\mathrm{K}: \mathrm{P}<3.4$.

Additionally, we collected soil samples at the three plots, on 17 September 2008. As described in Vittoz et al. (2006), the site has a microrelief with $S$. hirculus growing on c. $10 \mathrm{~cm}$ high mounds. Per plot, we took five samples of the soil in mounds just below the moss layer (c. $5 \mathrm{~cm}$ depth), and combined them to a mixed sample. Also, we took five samples in the hollows between the mounds $(0-10 \mathrm{~cm}$ depth $)$ and mixed them. The samples had a diameter of 4-5 cm and were taken with a sharp knife. Extractable $\mathrm{NO}_{3}$ and $\mathrm{NH}_{4}$, as well as $\mathrm{pH}-\mathrm{KCl}$, were determined after extraction with $0.2 \mathrm{M} \mathrm{KCl}$, extractable $\mathrm{PO}_{4}$ with $\mathrm{NaCO}_{3}$ (Olsen), and extractable $\mathrm{K}$ with $\mathrm{CH}_{3} \mathrm{COONH}_{4}$. All extractions were carried out on a shaking machine for an hour. Chemical analyses of $\mathrm{N}$ and $\mathrm{K}$ compounds in the extraction fluids were determined as in the Kjeldahl digests, $\mathrm{P}$ was measured on a photospectrometer (Uvi light XT2, Secomam, Domont, France). $\mathrm{pH}$-water was measured in $50 \mathrm{ml}$ distilled water 24 hours after $20 \mathrm{~g}$ fresh soil was added. The $\mathrm{pH}$ was measured with a $744 \mathrm{pH}$-meter (Metrohm, Herisau, Switzerland) after stirring.

\section{Results}

In all three Swiss plots, Saxifraga hirculus was a dominant species. Other species with a high cover were Carex diandra, Carex rostrata, Potentilla palustris, and in some plots Carex limosa, Caltha palustris or Valeriana dioica. Noteworthy, two other Red List species and two potentially threatened species occurred in these three plots (Tab. 1). Eighteen species of the Swiss site also occurred in the Polish and Russian sites (Tab. 1).

Aboveground biomass of vascular plants at the Swiss site was low with 152 $231 \mathrm{~g} \mathrm{~m}^{-2}$ (Tab. 2). Tissue nutrient concentrations of the aboveground biomass were 13.3-15.1 mg N, 1.81-2.15 mg P, 13.4-16.3 mg K per g biomass. The corresponding $\mathrm{N}: \mathrm{P}$ ratio of $7.0-8.1, \mathrm{~N}: \mathrm{K}$ of $0.8-1.1$, and $\mathrm{K}: \mathrm{P}$ ratio of $6.6-8.9$ clearly indicate $\mathrm{N}-$ limitation. This also holds for the Polish site and site 1 from Russia, whereas sites 2-4 from Russia had higher N:P ratios (Tab. 2).

Soil extractable $\mathrm{N}$ concentrations as well as the $\mathrm{NH}_{4}: \mathrm{NO}_{3}$ ratio were generally low in the Swiss plots, except for one higher $\mathrm{NH}_{4}$ value (Tab. 2). In mounds, where S. hirculus is 
Tab. 1. Composition of vascular plant community of the last remaining vegetation with Saxifraga hirculus in Switzerland (three $2 \times 2 \mathrm{~m}$ plots at one site), as well as corresponding values from sites with $S$. hirculus in Poland and Russia. The Polish site was recorded in 1987, it was located in a dwarf shrub community Betuletum humilis (Wassen et al. 1990). The Russian sites were located in the valley of the Ob river in Siberia (Schipper et al. 2007) in a Carex lasiocarpaParnassia palustris community (Tanneberger and Hahne 2003). Site 1 was recorded in 2001, sites 2, 3 and 4 were recorded in 2003. Vegetation cover is shown as percentage of soil surface and plant cover is estimated with the Braun-Blanquet (1964). Cover: $r$, rare;,$+<1 \% ; 1,1-5 \%$; $2,5-25 \% ; 3,25-50 \%$. $\times$, species was present but data on cover is not available. '-'value was not determined.

\begin{tabular}{|c|c|c|c|c|c|c|c|c|}
\hline & \multicolumn{3}{|c|}{ Switzerland } & \multirow{2}{*}{$\begin{array}{l}\text { Poland } \\
\text { Site } 1\end{array}$} & \multicolumn{4}{|c|}{ Russia } \\
\hline & Plot A & Plot B & Plot C & & Site 1 & Site 2 & Site 3 & Site 4 \\
\hline Cover herb layer (\%) & 80 & 70 & 75 & 65 & 50 & 35 & 60 & - \\
\hline Cover bryophyte layer (\%) & 60 & 85 & 95 & 50 & 70 & 90 & 35 & - \\
\hline No. vascular plants & 23 & 18 & 14 & 25 & 23 & 21 & 27 & 24 \\
\hline No. vasc. plants on Swiss Red List & 2 & 3 & 2 & 5 & 6 & 4 & 8 & 5 \\
\hline No. bryophytes & - & - & - & 7 & 4 & $\geq 2$ & $\geq 2$ & $\geq 2$ \\
\hline Saxifraga hirculus ${ }^{2}$ & 2 & 2 & 2 & $\mathrm{r}$ & 2 & $x$ & $x$ & $x$ \\
\hline Carex diandra ${ }^{3}$ & + & 3 & 2 & & 2 & $x$ & $x$ & $x$ \\
\hline Carex rostrata & 2 & + & 1 & 1 & & & $x$ & $x$ \\
\hline Potentilla palustris & 1 & 2 & 2 & 1 & & $x$ & $x$ & $x$ \\
\hline Euphrasia montana & 1 & + & + & & & & & \\
\hline Epilobium palustre & + & 1 & + & & 2 & & & \\
\hline Dactylorhiza incarnata ${ }^{4}$ & + & $\mathrm{r}$ & 1 & & & & & \\
\hline Agrostis stolonifera & + & + & + & & & $x$ & & $x$ \\
\hline Cardamine pratensis & + & + & $\mathrm{r}$ & & 1 & & & \\
\hline Eriophorum angustifolium & + & + & + & & + & & & \\
\hline Poa pratensis & $\mathrm{r}$ & $\mathrm{r}$ & + & + & + & $x$ & $x$ & $x$ \\
\hline Carex nigra & + & + & & & & & & \\
\hline Galium palustre & + & + & & & 1 & $x$ & $x$ & $x$ \\
\hline Caltha palustris & 2 & & 1 & $\mathrm{r}$ & & & & \\
\hline Carex limosa $a^{4}$ & + & & 2 & & 2 & $x$ & $x$ & $x$ \\
\hline Rumex acetosa & & 1 & + & & 1 & $\times$ & $x$ & $\times$ \\
\hline Valeriana dioica & 2 & & & & & & & \\
\hline Eleocharis quinqueflora & 1 & & & & & & & \\
\hline Silene flos-cuculi & 1 & & & + & & & & \\
\hline Swertia perennis ${ }^{4}$ & 1 & & & & & & & \\
\hline Carex davalliana & + & & & & & & & \\
\hline Equisetum fluviatile & $\mathrm{r}$ & & & 1 & & $x$ & & \\
\hline Parnassia palustris & + & & & + & 2 & $x$ & $x$ & $x$ \\
\hline Succisa pratensis & + & & & & & & & \\
\hline Blysmus compressus & & + & & & & & & \\
\hline Galium uliginosum & & + & & + & 2 & $x$ & $x$ & $x$ \\
\hline Sagina nodosa ${ }^{3}$ & & + & & & & & & \\
\hline Festuca rubra agg. & & $\mathrm{r}$ & & 1 & & & & \\
\hline Betula humilis $^{1}$ & & & & 2 & & & & \\
\hline Salix cinerea & & & & 2 & & & & \\
\hline Salix pentandra ${ }^{4}$ & & & & + & & & & \\
\hline Salix repens ${ }^{4}$ & & & & 1 & & & & \\
\hline Calamagrostis stricta & & & & $\mathrm{r}$ & + & & & $x$ \\
\hline Carex appropinquata & & & & 3 & & & & \\
\hline
\end{tabular}


Tab. 1. (continued)

Switzerland

Poland Russia

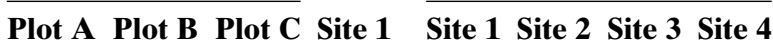

Cirsium palustre

Filipendula ulmaria

Lysimachia thyrsiflora ${ }^{3}$

Lythrum salicaria

Menyanthes trifoliata

Myosotis palustris

Oxycoccus palustris ${ }^{4}$

Ranunculus lingua ${ }^{3}$

Stellaria palustris ${ }^{1}$

Epipactis palustris

Carex chordorhiza ${ }^{3}$

Stellaria crassifolia

Cicuta virosa/tenuifolia ${ }^{2}$

Agrostis gigantea

Triglochin maritimum

Herminium monorchis ${ }^{4}$

Eriophorum gracile ${ }^{2}$

Liparis loeselii ${ }^{3}$

Agrostis canina $^{4}$

Carex dissica

Carex lasiocarpa ${ }^{4}$

Epilobium fungi

Peucedanum palustre ${ }^{4}$

Pedicularis palustris

Utricularia intermedia ${ }^{2}$

Orchis incorvatia

Triglochin palustre

Thelypteris palustris ${ }^{3}$

Carex triculca

Hydrocharis morsus-ranae ${ }^{2}$

Lemna minor

Lycopus sp.

Typha angustifolia ${ }^{4}$

\section{r}

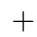

1

$+$

2

r

2

r

r

$\begin{array}{cccc}2 & & & \\ 2 & \times & \times & \times \\ 1 & & & \\ 1 & & \times & \\ 1 & & & \\ 1 & & & \\ + & & \times & \times \\ + & & & \\ & \times & \times & \times \\ & \times & \times & \times \\ & \times & \times & \times \\ & \times & \times & \times \\ & \times & \times & \times \\ & & \times & \times \\ & & \times & \times \\ & \times & & \times \\ & \times & & \times \\ & \times & \times & \\ & \times & \\ & & \times & \\ & & \times & \\ & & \\ & & \\ & & \end{array}$

Status according to the Swiss Red list (Moser et al. 2002): ${ }^{1}$ extinction threatened, ${ }^{2}$ strongly endangered, ${ }^{3}$ vulnarable, ${ }^{4}$ not on the Red List but indicated as potentially threatened.

rooting, $\mathrm{NH}_{4}$ concentrations were below the detection limit $\left(<1 \mathrm{mg} \mathrm{NH}-\mathrm{N} \mathrm{kg}^{-1}\right)$. In contrast, extractable $\mathrm{P}$ concentrations (209-450 $\mathrm{mg} \mathrm{kg}^{-1}$ ) and $\mathrm{K}$ concentrations (364-1486 mg kg-1) were rather high (Tab. 2). The Swiss, Polish and Russian sites all had a $\mathrm{pH}$ close to neutral. The $\mathrm{pH}$ as well as $\mathrm{P}$ and $\mathrm{K}$ concentrations tended to be higher in the mounds than in the hollows (Tab. 2). 


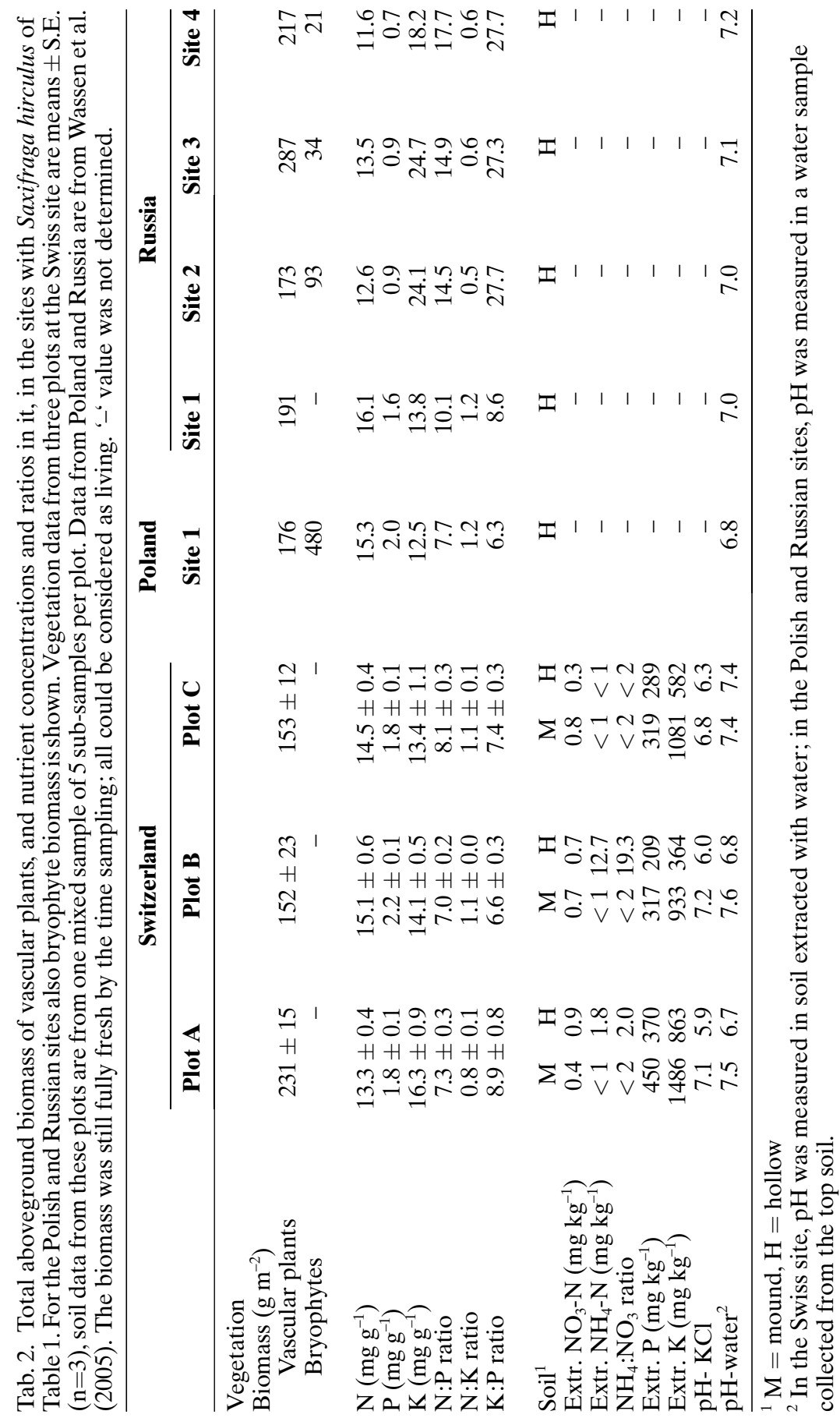




\section{Discussion}

Biomass production of the last vegetation containing Saxifraga hirculus in Switzerland was clearly N-limited. Hence, conservation management should first of all focus on measurements preventing $\mathrm{N}$-enrichment. Particularly manure or mineral fertilization should be avoided, as well as drainage since drainage of wetlands often stimulates N mineralization and N availability (Grootjans et al. 1985; Laine et al. 1995; Olde Venterink et al. 2002a). Another major N input source in Swiss fens, however, is atmospheric deposition (15-30 kg N ha $\mathrm{yr}^{-1}$ in the Jura; BUWAL 2005) which can only marginally be controlled by local management.

The tissue nutrient concentrations of the Swiss site were very similar to those of the Polish site and one of the Russian sites (site 1 ). All had relatively high P concentrations and had N:P ratios far below the threshold of 14.5 (Tab. 2), so they were clearly Nlimited. The other Russian sites had slightly lower $\mathrm{N}$ concentrations, but clearly lower $\mathrm{P}$ concentrations, resulting in higher $\mathrm{N}: \mathrm{P}$ ratios. These $\mathrm{N}: \mathrm{P}$ ratios, above 14.5 , indicate that $\mathrm{N}$ and $\mathrm{P}$ could be co-limiting, or P could be limiting. Ohlson (1988) determined tissue nutrient concentrations in S. hirculus and co-occurring species in seven Swedish mires. Due to relatively low $\mathrm{N}$ and high $\mathrm{P}$ concentrations, all species had average N:P ratios below 10, indicating N-limitation. S. hirculus had a lower N:P ratio than its competitors. $S$. hirculus is a clear example that not all endangered plant species of wetlands persist better at P-limited conditions. Also in Wassen et al. (2005), there were $1-3$ endangered species that persisted better at N-limited sites $(4-16 \%$ of the evaluated species), $0-2$ species at NP co-limited sites ( $0-20 \%)$, and up to 11 species that had no preference $(0-47 \%)$ with variation in species numbers among areas.

The aboveground biomass of the vascular plants was consistently low (150-300 $\left.\mathrm{g} \mathrm{m}^{-2}\right)$ among the Swiss, Polish and Russian sites with S. hirculus (Tab. 2), as well as a fen in Scotland containing S. hirculus (Welch and Rawes 1964). Maintaining a low biomass is decisive for endangered species (Wassen et al. 2005). To keep the biomass low at the Swiss site, with an atmospheric $\mathrm{N}$ deposition of $15-30 \mathrm{~kg} \mathrm{~N}^{-1} \mathrm{y}^{-1}$ (BUWAL 2005), it seems necessary to apply grazing or mowing. The site is lightly grazed by young bovines which apears to have a positive influence on $S$. hirculus performance by reducing the competition by Carex species (Vittoz et al. 2006). Studies in Scotland and Sweden also showed that low intensity grazing or annual haymaking had a positive influence on populations of $S$. hirculus (Welch and Rawes 1964; Ohlson 1986, 1989). The Polish and Russian sites are not managed and only grazed by wild herbivores, but this may be only possible because of the lower $\mathrm{N}$ deposition rates in these areas $\left(5-10\right.$ and $<5 \mathrm{~kg} \mathrm{~N} \mathrm{ha}^{-1} \mathrm{y}^{-1}$ respectively; Wassen et al. 2005). It should, however, be realized that grazing or haymaking may cause a shift from $\mathrm{N}$ to $\mathrm{P}$ or $\mathrm{K}$ limitation in the long-tem (Olde Venterink et al. 2002b), and consequences of such a shift for vegetation composition are unclear (Güsewell 2004).

Recently, Kleijn et al. (2008) compared peat water quality of heathlands and acid grasslands with endangered species with that of comparable sites with only common species. They found that the water quality differed mainly with respect to $\mathrm{NH}_{4}$ concentration and the $\mathrm{NH}_{4}: \mathrm{NO}_{3}$ ratio. Endangered species did not occur at sites with a high $\mathrm{NH}_{4}$ concentration or a high $\mathrm{NH}_{4}: \mathrm{NO}_{3}$ ratio. Our results of the Swiss site are consistent with this pattern: $\mathrm{NH}_{4}, \mathrm{NO}_{3}$ and their ratio, are in the range for rare species of Kleijn et al. (2008). However, Ohlson (1988) found clearly higher $\mathrm{NH}_{4}$ concentrations, but low $\mathrm{NO}_{3}$ concentrations, for Swedish mires with $\mathrm{S}$. hirculus. We note that $\mathrm{NH}_{4}$ may particularly become toxic at acid conditions (Lucassen et al. 2002; van den Berg et 
al. 2005), and therefore $\mathrm{NH}_{4}$ toxicity is not likely to take place at the neutral soils where S. hirculus occurs (Tab. 2).

Soil extractable P concentrations were higher in the Swiss site than in the Swedish sites of Ohlson (1988), but K concentrations were similar (Swedish sites: 500-2100 mg $\mathrm{K} \mathrm{kg}^{-1}$ and $<10-210 \mathrm{mg} \mathrm{P} \mathrm{kg}^{-1}$ ). Compared to other fens (Bollens et al. 2001; Olde Venterink et al. 2001), both $\mathrm{P}$ and $\mathrm{K}$ concentrations were rather high, which supports that $\mathrm{N}$ is growth-limiting. It is worth mentioning that, due to a very low bulk density in the Swiss site, concentrations of all three nutrients will be relatively low when calculated per soil volume.

Högbom and Ohlson (1991) found that S. hirculus had a higher nitrate reductase activity than Carex rostrata and concluded that this may be a competitive advantage when pulses of nitrate are released. However, in Swedish mires the main competitors for $S$. hirculus, in particular C. rostrata, responded much stronger to differences in soil N (mainly available as ammonium), P and K concentrations than S. hirculus (Ohlson 1986, 1988). Hence, it can be expected that an increased availability of the limiting nutrient (N in the Swiss site) will particularly benefit the competing Carex species and likely harm $S$. hirculus.

Vittoz et al. (2006) suggested some possibilities to conserve and restore S. hirculus populations (grazing, mowing, reintroduction, management of soil surface). The results of the present study confirm that a low aboveground biomass and a low availability of particularly nitrogen are important and ought to be considered in the context of pasture management and before reintroduction trials. We note that besides $S$. hirculus, the Swiss, Polish and Russian sites contained many species that are endangered in Switzerland or other Western European countries (Tab. 1). This indicates that restoration or recreation of habitat conditions that might harbour S. hirculus (e.g. constant high water table, neutral $\mathrm{pH}$ and low $\mathrm{N}$ availability) are likely favourable for other endangered wetland plants as well.

\section{Résumé}

Pour améliorer la protection des plantes menacées, il est important de connaître quel(s) nutriment(s) limite(nt) la croissance de la végétation. En effet, le maintien d'une faible teneur en azote $(\mathrm{N})$, en phosphore $(\mathrm{P})$ ou en potassium $(\mathrm{K})$ nécessite des mesures de gestion différentes. Le but de cette étude était d'identifier quel nutriment est limitant dans le marais hébergeant la dernière population suisse de Saxifraga hirculus, en utilisant comme indicateur le rapport entre les différents nutriments mesurés dans les plantes. Nous avons effectué des relevés floristiques et collecté la biomasse aérienne des plantes vasculaires et des échantillons de sols dans trois parcelles contenant $S$. hirculus. La biomasse était très basse $\left(152-231 \mathrm{~g} \mathrm{~m}^{-2}\right)$ et les trois sites étaient clairement limités par $\mathrm{N}$, avec un rapport $\mathrm{N}: \mathrm{P}$ de $7-8$. Les concentrations de $\mathrm{N}$ échangeable étaient généralement basses, alors que les concentrations de $\mathrm{P}$ biodisponible et $\mathrm{K}$ échangeable étaient moyennes à hautes, ce qui est cohérent avec une végétation limitée par N. Pour conserver $S$. hirculus, il est donc important d'éviter un apport de fertilisants azotés dans le marais, de ne pas favoriser la minéralisation de la tourbe par drainage et de limiter l'accumulation de l'azote provenant de la pollution atmosphérique. De ce fait, la pâture ou la fauche peuvent être recommandées pour en retirer une partie. La gestion actuelle du marais, avec pâturage extensif, semble être 
idéale car la biomasse aérienne des plantes vasculaires est très faible et $S$. hirculus est abondant dans sa dernière station.

We are grateful to Service des forêts, de la faune et de la nature (Canton de Vaud) for sampling authorization. We thank Rose Trachsler, Britta Jahn and Hans Göransson for chemical analyses of the Swiss biomass samples, and Martin Wassen for allowing the use of the data of the Polish and Russian sites. Jacques de Smidt recorded the vegetation at the Polish site, Elana Lapshina and Franziska Tanneberger at the Russian sites. We thank Martin Wassen, Sabine Güsewell, Sonja Wipf and two anonymous reviewers for their constructive comments on the manuscript.

\section{References}

Bobbink R., Hornung M. and Roelofs J.G.M. 1998. The effect of air-borne nitrogen pollutant on species diversity in natural and semi-natural European vegetation. J. Ecol. 86: 717-738.

Bollens U., Güsewell S. and Klötzli F. 2001. Vegetation changes in two Swiss fens affected by eutrophication and desiccation. Bot. Helv. 111: 121-137.

Braun-Blanquet J. 1964. Pflanzensoziologie. Grundzüge der Vegetationskunde. 3rd edn. Springer, Wien.

Broennimann O., Vittoz P., Moser D. and Guisan A. 2005. Rarity types among plant species with high conservation priority in Switzerland. Bot. Helv. 115: 95-108.

BUWAL 2005. Stickstoffhaltige Luftschadstoffe in der Schweiz. Status-Bericht der Eidg. Kommission für Lufthygiene. Schriftenreihe Umwelt Nr. 384. Bundesamt für Umwelt, Wald und Landschaft, BUWAL, Bern. (http://www.bafu.admin.ch/luft/00612/00624/)

Christe P., Glaizot O., Delarze R. et Hainard P. 1990. La végétation du marais des Amburnex (Jura vaudois, Suisse). Bull. Soc. Vaud. Sci. Nat. 80: 127-139.

Davidson E.A. and Howarth R.W. 2007. Nutrients in synergy. Nature 449: 1000-1001.

Delarze R. et Gonsetz Y. 2008. Guide des milieux naturels de Suisse. Rossolis, Bussigny.

Eggenberg S. und Landolt E. 2006. Für welche Pflanzenarten hat die Schweiz eine internationale Verantwortung? Bot. Helv. 116: 119-133.

Hunt J. 1982. Dilute hydrochloric acid extraction of plant material for routine cation analysis. Commun. Soil. Sci. Plan. 13: 49-55.

Galloway J.N., Dentener F.J., Capone D.G., Boyer E.W., Howarth R.W., Seitzinger S.P., Asner G.P., Cleveland C.C., Green P.A., Holland E.A., Karl D.M., Michaels A.F., Porter J.H., Townsend A.R. and Vörösmarty C.J. 2004. Nitrogen cycles: past, present, and future. Biogeochemistry 70: 153-226.

Grootjans A.P., Schipper, P.C. and van der Windt H.J. 1985. Influence of drainage on Nmineralization and vegetation response in wet meadows: I Calthion palustris stands. Acta Oecol. 6: 403-417.

Güsewell S. 2004. N:P ratios in terrestrial plants: variation and functional significance. New. Phytol. 164: 243-266.

Högbom L. and Ohlson M. 1991. Nitrate assimilation in coexisting vascular plants in mire and swamp forest habitats in Central Sweden. Oecologia 87: 495-499.

Kleijn D., Bekker R.M., Bobbink R., de Graaf M.C.C. and Roelofs J.G.M. 2008. In search for key biogeochemical factors affecting plant species persistence in heathland and acid grasslands: a comparison of common and rare species. J. Appl. Ecol. 45: 680-687.

Laine J., Vasander H. and Laiho R. 1995. Long-term effects of water level drawdown on the vegetation of drained pine mires in southern Finland. J. Appl. Ecol. 32: 785-802.

Lauber K. et Wagner G. 2000. Flora Helvetica. Haupt, Berne

Lucassen E., Bobbink R., Smolders A.J.P., van der Ven P.J.M., Lamers L.P.M. and Roelofs J.G.M. 2002. Interactive effects of low $\mathrm{pH}$ and high ammonium levels responsible for the decline of Cirsium dissectum (L.) Hill. Plant Ecol. 165: 45-52. 
Moore D.R.J., Keddy P.A., Gaudet C.L. and Wisheu I.C. 1989. Conservation of wetlands: do infertile wetlands deserve a higher priority? Biol. Conserv. 47: 203-217.

Moser D., Gygax A., Bäumler B., Wyler N. et Palese R. 2002. Liste rouge des fougères et plantes à fleurs menacées de Suisse.Office fédéral de l'environnement, des forêts et du paysage, Berne.

Ohlson M. 1986. Reproductive differentiation in Saxifraga hirculus population along an environmental gradient on a central Swedish mire. Holarctic Ecol. 9: 205-213.

Ohlson M. 1988. Variation in tissue element concentration in mire plants over a range of sites. Holarctic Ecol. 11: 267-279

Ohlson M. 1989. Dynamik i nord- och mellansvenska populationer av myrbräcka. Svensk Bot. Tidskr. 83: 1-11.

Olde Venterink, H., Wassen M.J., Belgers J.D.M. and Verhoeven J.T.A. 2001. Control of environmental variables on species density in fens and meadows; importance of direct effects and effects through community biomass. J. Ecol. 89: 1033-1040.

Olde Venterink H., Davidsson T.E., Kiehl K. and Leonardson L. 2002a. Impact of drying and rewetting on N, P and K dynamics in a wetland soil. Plant Soil 243: 119-130.

Olde Venterink H., Pieterse N.M., Belgers J.D.M., Wassen M.J. and De Ruiter P.C. 2002b. N, P and $\mathrm{K}$ budgets along nutrient availability and productivity gradients in wetlands. Ecol. Appl. 12: 1010-1026.

Olde Venterink H., Wassen M.J., Verkroost A.W.M. and De Ruiter P.C. 2003. Species richnessproductivity patterns differ between N-, P- and K-limited wetlands. Ecology 84: 2191-2199.

Schipper A.M., Zeefat R., Tanneberger F., van Zuidam J.P., Hahne W., Schep S.A., Loos S., Bleuten W., Joosten H., Lapshina E.D. and Wassen M.J. 2007. Vegetation characteristics and eco-hydrological processes in a pristine mire in the Ob River valley (Western Siberia). Plant Ecol. 193: 131-145.

Stevens C.J., Dise N.B., Mountford J.O. and Gowing D.J. 2004. Impact of nitrogen deposition on the species richness of grasslands. Science 303: 1876-1879.

Tanneberger F. and Hahne W. 2003. Landscape ecology and palaeo-ecology of Ob valley mires near Tomsk/Western Siberia. Diploma Thesis Ernst-Moritz-Arndt University, Greifswald.

van den Berg L.J.L., Dorland E., Vergeer P., Hart M.A.C., Bobbink R. and Roelofs J.G.M. 2005. Decline of acid-sensitive plant species in heathland can be attributed to ammonium toxicity in combination with low pH. New Phytol. 166: 551-564.

Verhoeven J.T.A., Keuter A., van Logtestijn R., van Kerkhoven M.B. and Wassen M.J. 1996. Control of local nutrient dynamics in mires by regional and climatic factors: a comparison of Dutch and Polish sites. J. Ecol. 84: 647-656.

Vittoz P., Wyss T. and Gobat J.M. 2006. Ecological conditions for Saxifraga hirculus in Central Europe: A better understanding for a good protection. Biol. Conserv. 131: 594-608.

Wassen M.J., Barendregt A., Palczynski A., De Smidt J.T. and De Mars H. 1990. The relationship between fen vegetation gradients, groundwater flow and flooding in an undrained valley mire at Biebrza, Poland. J. Ecol. 78: 1106-1122.

Wassen M.J., Olde Venterink H., Lapshina E.D. and Tanneberger F. 2005. Endangered plants persist under phosphorus limitation. Nature 437: 547-550.

Weeda E.J., Westra R., Westra C. en Westra T. 1985. Nederlandse Ocologische Flora; Wilde Planten en hun Relaties, Deel 1. IVN, Amsterdam.

Welch D. and Rawes M. 1964. The early effects of excluding sheep from high-level grasslands in the North Pennines. J. Appl. Ecol. 1: 281-300.

Welch D. 2002. The establishment of recovery sites for Saxifraga hirculus L. in NE Scotland. Bot. J. Scotland 54: 75-88.

Wheeler B.D. and Shaw S.C. 1991. Above-ground crop mass and species richness of the principal types of herbaceous rich-fen vegetation of lowland England and Wales. J. Ecol. 79: 285-301.

Submitted 5 June 2008

Accepted 14 October 2008

Subject editor: Sonja Wipf 